\title{
A HISTORICAL REVIEW OF LEADERSHIP DEVELOPMENT IN THE FFA AND 4-H
}

\author{
Tracy S. Hoover, Professor \\ Jan F. Scholl, Associate Professor \\ The Pennsylvania State University \\ Anne H. Dunigan, Program Analyst, USDA \\ Nadezhda Mamontova, International Program Support Coordinator
}

\begin{abstract}
FFA and 4-H are two youth-based organizations that cite leadership development as a key foundational component. The purpose of this study was to review and document the historical development of leadership events and activities in both programs. Evidence can be found of leadership development in schools, conferences, and camps. Leadership-related events evolved into public-speaking contests, debates, farm demonstrations, and implementation of chapter and club programs of activities. Leadership resources from both organizations include official manuals, convention proceedings, advisor/leader handbooks, textbooks, and state and national magazines. Historically, both organizations provided members multiple opportunities to develop leadership behaviors, skills, and characteristics through knowledge and skill acquisition, participation in community and civic activities, and in the transition into the workforce and/or postsecondary education.
\end{abstract}

\section{Introduction}

Within the past five years $4-\mathrm{H}$ and the FFA celebrated landmark anniversaries, 100 and 75 years, respectfully. These landmark occasions are tribute to the value and worth of these organizations in the development of young people. Embedded in the very fabric of the mission and vision of these organizations are not only the attainment of agriculture and agriculture-related knowledge, but also leadership development. Even as early as 1913, youth involved in agricultural pursuits were sent on award trips to Washington, D.C. to learn leadership and citizenship skills (United States Department of Agriculture [USDA], 1913).

FFA: In 1950, Hammonds noted that leadership was one of the foundations upon which the Future Farmers of America (FFA) was built. Leadership activities, career development events, and training programs some developed many years ago and others more recently developed are being utilized today. After three-quarters of a century, leadership is still a core component in the FFA and is evident in the National FFA mission statement "FFA makes a positive difference in the lives of students by developing their potential for premier leadership, personal growth and career success through agricultural education" (National FFA, 2000b, p. 24).

4- $H$ : The leadership component of 4-H was there nearly from the start (Howes, personal communication, March 5, 2005) and as the organization matured, active membership was a natural source of future leadership (Wessel \& Wessel, 1982). Shinn (1928) stated that "the training in leadership is the most valuable part of the education these boys and girls derived from club work" (p. 7). Junior or 4-H teen leaders were supported by training at state, regional, and national camps and conferences.

As with FFA, 4-H leadership participation helped young people learn better practices and enhanced their personal growth. One 4-H member commented that it helped deepen "his ability to work well with others in club activities and in more casual peer and boy-girl relations" (Wessel \& Wessel, 1982, p. 123).

For the most part, youth organizations were formed to provide young people with 
opportunities for leadership and personal growth, career exploration, affiliation with others who share similar interests and beliefs, to have a place to belong, and/or to receive recognition for individual and group accomplishments. Examples of youth organizations and their key developmental principles are 4-H clubs which were formed in the early 1900s to provide young boys and girls an opportunity to learn more about agriculture and home economics education through "hands-on" learning methods (National 4-H, 2004; Vines \& Anderson, 1976).

Also in the early $1920 \mathrm{~s}$, the USDA created cooperative organizations for farm boys and girls (Credle, 1922).

\section{Objective}

The objective of this study was to provide a historical review of leadership development programming, components, events, and activities of two prominent agricultural youth programs, FFA and 4-H. The findings are organized in categories that reflect contributions to leadership development of members and their advisors/leaders. Some of the categories reflect direct leadership development events or programming such as, leadership conferences, curricula, and awards. Incidental or more indirect leadership programming and resources are found within other categories. The categories are as follows: formal education and leadership development; early leadership education nonformal and formal; 4-H and FFA leadership based activities, events and resources; leadership schools, conferences, and camps; leadership related competitive events; leadership related degrees; professional development resources; and graduate research in leadership development. We hope that this study will assist contemporary youth practitioners gain an understanding about the historical origins and related leadership development principles, practices, events, and resources.

\section{Methods}

A historical process research method was utilized to meet the objective of the study. Historical process research focuses on a series of events that happen over a long period of time (Schutt, 2001). The objective for the study guided the literature search, data collection components, and subsequent content analysis of data (Fraenkel \& Wallen, 1999). Results and findings were reported in a case-oriented historical narrative format (Schutt). Both primary and secondary sources were used in the research. Primary sources included books, films, letters, research reports, theses, and articles. Secondary data sources included books, government publications, educational materials and articles. More than 60 studies, documents and interviews were collected from major land-grant libraries, departmental and Web-based archives, the National FFA Center, the National 4-H Council, and the National Agricultural Library. Because historical research can be based only upon materials that have been saved, it should be understood that materials that make equivalent comparisons possible are not always available. Every effort has been made by the authors to include and document every possible resource so that readers may find these materials and build upon these research findings.

\section{Findings by Category}

\section{Formal Education and Leadership Development}

The historical importance of leadership and curriculum development was apparent long before the inception of youth organizations in the United States. Most youth "clubs" developed from roots in Europe before the 20th century. Early boys' clubs were often said to be a kind of school (Forbush, 1909). But these clubs also encouraged play and friendship as an important relational component of leadership development. In 1914, 4-H was formalized through the Smith-Lever Act, though its roots had been developing for more than a decade. In 1917, the SmithHughes Act provided funding to support vocational education in secondary public school programs to meet labor and industry demands for a skilled workforce in the United States. Vocational agriculture was 
one of the technical programs supported in this landmark piece of legislation. The National Future Farmers of America was founded in 1928 to provide fellowship and leadership development for youth enrolled in vocational agriculture programs (National FFA, 2005). Youth-based literature written about 4-H and FFA in the 1920s, 1930s, and 1940 s promoted the joining of agricultural clubs as an opportunity and path for higher education (Scholl, 2005b).

\section{Early Leadership Education Nonformal and Formal}

At the International Congress of Education in 1892, a French primary school educator, Ferdinand Buisson expounded the philosophy of the 3 H's head, heart, and hands that formed the basis of the 3-leaf clover. William Beardshear, president of Iowa State College, endorsed Buisson's philosophy in a speech given in Minneapolis in 1902 (Beardshear 1904; National Education Association, 1858-1952). The fourth $\mathrm{H}$ in $4-\mathrm{H}$ was said to have stood for "hussle" or "home" before "health" was adopted in 1911 (Wessel \& Wessel, 1982).

Before the Smith-Lever Act of 1914, the 4-H "philosophy" was supported by many rural school superintendents. Among the most noted were O.H. Benson from Iowa (Benson \& Warren, 1920), Albert Graham from Ohio (Graham, 1902-1952), Jessie Field Shambaugh of Iowa (Shambaugh, 1911), and Martha Van Rensselaer of New York (Van Rensselaer, 1900-1905). All were concerned with making the education of rural youth relevant to future vocations and organized agricultural experiments for students outside the classroom.

It is not known why FFA started later than 4-H, given the interest of school teachers and superintendents. Legislatively, the Smith-Lever Act of 1914 and the SmithHughes Act of 1917 were not so far apart. Some speculate that schools sanctioned a more formal curriculum in vocational and technical-based educational programs. Once the vocational programs were established, administrators and instructors could begin to focus on leadership development and programming for students.

In fact, the possibility of competition and duplication between 4-H and FFA concerned the leaders of both organizations as early as 1918. By 1928, the secretary of agriculture and the director of the Federal Board for Vocational Education established a joint committee that identified " $4-\mathrm{H}$ as a problem oriented project and vocational education as a systematic course or courses of instruction in basic agriculture" (Wessel \& Wessel, 1982, p. 46).

\section{Leadership-based Activities, Events, and Resources}

4- $H$. In the late $1800 \mathrm{~s}$, Liberty Hyde Bailey of New York developed a nature study correspondence course for youth, a forerunner of 4-H project book. Seaman Knapp, former president of Iowa State College, endorsed the concept of the demonstration method of education (Knapp, 1904). These educators not only taught recommended practices, but the results served as visual evidence used to encourage others to adopt similar practices (Frysinger, 1931).

The development of leadership in the 4-H program evolved around the 4-H projects and demonstrations given by youth to their peers. Demonstrations were a way of showing how well the new practices worked by applying knowledge learned. There was an underlying philosophy that youth would also teach new agricultural practices to their parents (USDA, 1920b). Project record books documented the progression of learning and skill development "that couldn't be seen" in an exhibit.

Because 4-H clubs, especially community clubs, taught a variety of projects skills and generally enrolled youth of all ages, the focus of 4-H leadership was often assisting new and younger members with their projects. Trips were made to the land-grant university for training, competition, and to improve project work. Short courses and/or "camps" provided upto-date information and skill development.

FFA: Evidence of leadership development is found even in the most dated publications. According to the 1938 Official FFA Manual:

The FFA organization affords an excellent opportunity to teach vocational students some of the fundamental 
principles of group leadership. The exercise of responsibility and working together in groups toward worthwhile goals are important elements in training for leadership and cooperative activity (National FFA, 1938, p. 5).

Furthermore, Stewart and Getman note the value of projects and club work in their 1927 text Teaching Agricultural Vocations - A Manual for Teachers in Preparation and Inservice "club meetings constitute one of the most valuable agencies for civic, social and leadership training" (p. 95). In 1939, Ross published Forward FFA-Leadership for Future Farmers, Agriculturists and Advisors which provided advisors a resource to teach leadership and provide guidance for FFA chapter procedures and activities.

In the 1917 Smith-Hughes Act, youth enrolled in secondary vocational agriculture programs were required to maintain a farm project that was six months in length. Prior to 1917 supervised farming projects were part of the curriculum for youth enrolled in many vocational agricultural education programs (Moore, 1988). In 1908, Rufus Stimson, director at the Smith's Agricultural School in Massachusetts, implemented the farm project method to provide youth an opportunity to apply concepts and practices learned in school to the home farm (Moore) Throughout the years, these farm projects have evolved to current-day Supervised Agriculture Experience (SAE) Projects which reflect a diverse array of projectbased learning that ranges from productionbased to research-based projects. Youth enrolled in agricultural education programs used record books to catalog SAE financial transactions, observations, leadership activities, and participation in related career development events.

\section{Leadership Schools, Conferences, and Camps}

4-H. Horace A. Moses, president of the Strathmore Paper Company in 1923, funded one of the first 4-H leadership training "schools," inviting one outstanding member from each of the ten eastern states (later, from 38 states and Canada) for a week-long training. Camp Vail located in Massachusetts, may have been one of these training schools (Montgomery, 1928; USDA, 1920a). Counties, states, and regions held camps and conferences as well, providing older 4-H members the opportunity to develop their leadership skills as camp counselors.

At the national level, the National 4-H Club Camp was first held in Washington, D.C. and visited by Eleanor Roosevelt (USDA, 1927). It later became the National 4-H Conference which was located at the National 4-H Center in Chevy Chase, Maryland. Citizenship Short Course (now Citizenship Washington Focus) was also held at the 4-H Center. Both the conference and the short courses incorporated leadership skills into their programs. Leadership development was also provided to the adult volunteers in leadership forums.

$F F A$. Soon after the FFA officially began in 1928, FFA advisors began to plan, implement, and collaborate on local FFA leadership schools, camps, and conferences (Tenney, 1977). These local leadership schools, camps, and conferences soon expanded to state- and national-level programs. Later, state leadership conferences became recognized as an important means to discover and apply abilities gained through the FFA (Vallot, 1963). Members of the Ohio Association met for their first FFA leadership conference in 1928 (Jackson, 1934). In 1935, Idaho FFA members met for a leadership training conference and discussed topics such as qualities of a leader and the essentials of a good chapter (Border, 1936). In 1935, the Oregon FFA met to discuss problems that were confronting chapters, factors necessary for a good chapter, becoming a successful officer, and developing a community service program (Duerst, 1935). In some states external support was provided for attendance at state leadership conferences. In 1937, the Danforth Foundation Award for Leadership Training provided Louisiana FFA members a scholarship to attend a twoweek leadership camp (Vallot).

In 1944, Pennsylvania held its first State Officer leadership training school. Participants were taught workshop procedures, group discussion techniques, committee work, parliamentary procedure, and preparation of an agenda and official 
reports (Knauer, 1950). These state officer schools lead to the development of area leadership training schools (Knauer). In 1959 the first national leadership training conference was held in Washington, D.C., with 250 state FFA officers in attendance. The success of the five-day conference led to an annual conference held in Washington, D.C. (Tenney, 1977).

Concurrently, many state associations began to include leadership components in their summer camp programs for chapter members and state officers. For example, the Couchdale FFA Camp was established in Arkansas in 1932 to give members educational practice in cooperative activities and leadership training (Smith, 1933). The Future Farmers of Kentucky included a leadership training component in their summer camp program in 1950. The purpose of the camp was for newly elected officers to receive training on public speaking and parliamentary procedure (Montgomery, 1950, as cited in Hoover, 1950).

\section{Leadership Related Competitive Events}

4-H. Each 4-H project had a state or nationally recognized record book that provided opportunities to document leadership concepts learned as well as skills developed in the project area. Illustrated talks or demonstrations were also important competitive events at local, state, and national levels. At the national level, presidential trays were given to the top $4-\mathrm{H}$ boy and girl in the areas of leadership, citizenship, and achievement (Wessel \& Wessel, 1982). Leadership award pins were provided to each county, but recognition also went to individuals in the form of trips to competitions or conferences as a way to meet new people and participate in leadership building activities.

$F F A$. As early as 1938, participation in leadership-related events was an important component of the organization and advancement in the FFA membership degree hierarchy.

Achievement of the individual is made the basis for advancement from rank to rank in the Future Farmers of America...Class work of a high order, developing a farming program, evidence of thrift, and a practical demonstration of leadership are some of the passports to the higher degrees of the organization (National FFA, 1938, p.4).

Leadership-related events in the early years of the FFA included debates, public speaking, community service, and membership on working committees (Wakefield, 1932). Soon the FFA began to capitalize on leadership-related events and developed contests (career development events) and activities that focused on leadership development and participation. For example, before 1950, leadership contests available to FFA members in Texas included public speaking, debates, news writing, farm demonstrations, and extemporaneous speaking (Hoover, 1950). In 1935, team competition in Virginia allowed chapters to deliver the FFA opening and closing ceremonies (Bryant, 2001). One of the earliest and most popular contests for FFA members was the public-speaking contest sponsored by the National FFA (Wakefield). The first national FFA public speaking contest occurred in 1930 at the third national convention and was broadcasted by CBS (Tenney, 1977).

The National Chapter Award Program recognizes excellence and completion of quality activities in a chapter's program of activities. This program allows members to work cooperatively reach chapter goals and secures recognition at the state and national level for their accomplishments (National FFA, 2000a). The first National Chapter Award program began in 1930 (Tenney, 1977). Evidence and demonstration of both group and individual leadership are needed for the successful planning and implementation of a chapter program of activities.

\section{Degrees}

4-H. 4-H participation was determined by the years enrolled, rather than by degrees. Leadership projects, for the most part, could be repeated by the member if new ideas and skills were targeted. In Pennsylvania, Robert Lewis developed a 4-H Teen Agent project (c. 1970) that allowed youth to take on leadership roles with increased 
responsibility, such as planning conferences. In the early 1960s $4-\mathrm{H}$ youth were provided the opportunity to create self-determined projects (Fenn, 1964), which represented motivation and self-governance.

$F F A$. In 1926, Henry Groseclose established the following degrees for the Future Farmers of Virginia: Greenhand, Virginia Farmer, and the Virginia Planter. In 1929, the degree of State Farmer was added to the degrees of membership (Virginia FFA Association, n. d.). In 1933, the National FFA Organization adopted the following degrees of membership: Greenhand, Future Farmer, State Farmer, and American Farmer. The Future Farmer degree was changed to the Chapter Farmer degree at the 1942 National Convention (Bryant, 2001).

Specific leadership-based accomplishments have been historically required for advancement through the FFA degree hierarchy. For example, in 1938, FFA members who wished to apply for the Future Farmer degree must have led a fifteen minute group discussion (National FFA, 1938). Even today, FFA members must document evidence of leadership behaviors and skills to advance through the levels of FFA degrees (National FFA, 2001). According to Bible (1954),

The satisfaction of achievement and work well done, such as earning the State and American Farmer degrees, developing a working partnership on the farm, performing the duties of an officer on the local, federation, state, and national level, all have their effect in the growth, attitudes, and leadership development of the individual (p. 124).

\section{Professional Development Resources}

$4-H$. Since the early days, nearly every state developed 4-H adult leader and junior leader manuals and record books. Some efforts were made to address leadership needs in project-specific content areas. Manuals were also developed for meeting management, for the development of the club officers, and to organize demonstrations and illustrated talks. Training materials were also provided for volunteer leaders and to professional extension youth agents at inservice meetings. Many of these training materials were developed as slide sets and later as video tapes.

Numerous national magazines were published for members and leaders, including the National Boys and Girls Club News (1923-1936), National 4-H Club News (1936-1947), National 4-H News (19471985), 4-H Leader: The national magazine for 4-H (1985-1988), and the 4-H Digest, published in the 1980s. States and counties published leader newsletters and, in some cases, state leader monographs and research summaries.

In most locations, radio was not an important communication tool for $4-\mathrm{H}$ as in FFA, but as early as 1913 silent black-andwhite films were created by USDA to document 4-H activities and literature. Likewise, Hollywood films such as Young America (Twentieth Century-Fox, 1934), Green Promise (RKO Pictures, Inc., 1949), and Tomboy and the Champ (Universal Pictures, 1961), modeled leadership roles and encouraged $4-\mathrm{H}$ members to advance their project work. Television was also popular. Indiana's Clover Power, hosted by the now-famous David Letterman, was one example (Letterman, 2002). But, by far the most popular motion picture, Mulligan Stew (USDA, 1973), focused on the dynamics of a $4-\mathrm{H}$ club that helped young people learn nutrition skills.

$F F A$. The increased emphasis and focus on leadership education and development resulted in a corresponding increase and in the creation of leadership curriculum and corresponding resources. As early as 1926 Virginia developed a publication for its FFV members called "Chapter Chats" (Virginia FFA Association, n. d.). On a national level, the delegates at the 1929 National FFA Convention recommended the development of an official manual and at the 1930 national convention, Henry Groseclose, the National FFA executive secretary, announced the release of the first FFA manual that would reflect changes in the structure and identify procedures used by the organization (National FFA, n. d.).

Delegates at the 1929 National FFA Convention also discussed the need for a magazine. However, due to lack of funding, the idea was ignored until 1945, when a 
brochure titled FFA in Action was distributed. This brochure served as the forerunner to the first national FFA magazine, The National Future Farmer (Tenney, 1977). The National Future Farmer was renamed New Horizons in 1989 (National FFA, 2001). The first advisor newsletter, Between Issues, was published in 1956 and was later renamed FFA Advisors Making a Difference in 1992 (National FFA, 2005).

The Agricultural Education Magazine, started in 1927, served not only as a resource for college professors and students, but as a resource for FFA advisors and members. Another form of communication was the use of the radio. On April 13, 1931, the first broadcast for the FFA was heard nationwide. Throughout the years of broadcasting, the radio programs provided evidence of the goals, projects, leadership based accomplishments, and membership characteristics of the organization (Hillison \& Williams, 2001).

Wall's book $A$ More Effective FFA (1960) was written for FFA members and their advisors to successfully carry out the duties and tasks of a local FFA chapter. He begins the text by discussing democracy, its presence, and importance to the FFA. Later Wall identifies two types of leadership: "formal, an elected or appointed position held by individuals who work and lead within formal groups" (p. 11) and "informal, a position bestowed upon a person by his fellows because of the respect they have for his ability and willingness to lead" (p. 12). In 1962, Bender and Taylor published The FFA and You: Your Guide for Learning for agricultural education students to help them maximize leadership, cooperation, and citizenship responsibilities available to them in the FFA (Bender \& Taylor, 1974).

Additional leadership related resources available for agricultural educators and FFA members included the FFA Advisors Handbook, first published in 1975, and the FFA Student Handbook, first published in 1977 (National FFA, n. d.). Another resource was the 1969 book titled Advisors Teaching Guide on FFA, which highlighted the importance of the FFA in agricultural education, organizational and operational procedures, and how to plan and conduct a chapter meeting, (National FFA, n. d.).

Research Studies about 4-H and FFA Development of Leadership and Content skills

A review of the graduate research literature from the $20^{\text {th }}$ century reveals more than 1,600 state, national and graduate studies with findings relative to 4-H (Scholl, 2004) and 200 FFA (Scholl, 2005a). Some institutions may have chosen to house studies in their department's rather than placing them in college libraries, which may account for the limited studies found for FFA. 4-H studies emphasized junior leadership, discovering personal values and personality, and the development of lasting leadership characteristics. Comparisons were made among members choosing leadership roles and whether involvement in leadership activities was a factor in retaining membership.

The primary focus of FFA leadership research was to determine whether FFA members and officers continue to be leaders after high school and/or if they retained a social participation in their communities (Scholl, 2005a). Perception studies of members, teachers, and principals about FFA leadership development programs were also prevalent. Graduate students studied 4-H and FFA leadership development life skills, though the actual skills studied varied from study to study.

\section{Conclusions/Implications}

Many youth groups and clubs were formed in the early 1900s to provide youth the opportunity to engage in leadership development, secure knowledge and skills, and provide recognition and rewards for accomplishment. This study identified and reviewed historical development of leadership in the FFA and 4-H programs. Primary and secondary data sources were used to collect information from major landgrant libraries, departmental and Web-based archives, the National FFA Center, National 4-H Council, and National Agricultural Library. 
Leadership development was evident within agricultural education clubs as early as 1927 (Stewart \& Getman, 1927) and, according to other sources, many years earlier. FFA and 4-H members were encouraged to develop leadership skills and behaviors at the local and state levels through schools, camps, conferences, and competitive events. Leadership-related events and contests evolved into publicspeaking contest, debates, extemporaneous speaking, and farm/home demonstrations. Participation in various programs and events were also acknowledged through attainment of degrees and awards. In reviewing the evidence gathered for this study it is important to note the differences in the programs related to their orientation (nonformal vs. formal education). As initially organized and developed, 4-H and FFA shared more similarities than differences as related to the personal growth and leadership development of young people. To date, both youth organizations are still providing subject matter and opportunities in life skill and leadership development to meet the needs of the twenty-first century.

Leadership-based resources and materials for FFA members and advisors and 4-H leaders and members may not have been as widely accessible as they are today, but the organizations were not without resources. Leadership-based resources included the official manuals and handbooks, project books, state and national magazines, resource guides, textbooks, radio, television, and motion pictures.

Currently, National FFA is using two principles to drive leadership-based programming and revise existing programs. One is the developmental continuum of "awareness, interaction, and mastery" to measure student learning and success (National FFA, 2006; Van Linden \& Fertman, 1998) which expands and is grounded in the FFA mission statement of "premier leadership, personal growth, and career success" (National FFA, 2000b, p. 24). The other leadership principle adopted by National FFA is the recognition that students move along a developmental continuum as they as mature and develop leadership skills. This principle has a strong experiential learning base and is based on leadership development of adolescents (Chickering, 1983; van Linden \& Fertman).

National 4-H continues to develop leadership skills among young people and volunteer leaders through projects and activities at the county, state, and national levels. For example, the Special Training in Spectacular Tradition (SPECTRA) Leadership Program challenges Texas young people to "keep their feet on the ground, while reaching for the stars" (Newberry, Couch, Howard \& Boleman, 2001, p.67). Youth continue to go to Club Congress, Washington Focus and many other state and national conferences. Volunteers have leader forums and extension educators belong to the National Association of Extension 4-H Agents (NAE4-HA). Research continues on the best methods of conducting leadership training in both programs.

This paper sought to review the leadership contributions of FFA and 4-H as youth development organizations. Aspects of leadership development and training were implemented and refined over many years, though specific activities, resources, venues, and events may have varied for youth in the two organizations. Educators, youth practitioners, and legislators need to continue to recognize the "value-added" leadership aspect as well as the cognitive and psychomotor skills gained through enrollment in youth organizations.

\section{References}

Beardshear, W. (1904). The three H's in education. In W. Beardshear. A boy again and other prose poems. Cedar Rapids, IA: Republican Printing.

Bender, R. \& Taylor, R. (1974). The FFA and you: Your guide to learning (2nd edition). Danville, IL: Interstate Printers \& Publishers.

Benson, O. \& Warren, G. (1920). Organization and results of boys' and girls' club work, 1918. Washington, D.C.: U.S. Department of Agriculture.

Bible, B. (1954, December). Rural Leadership Looks to the FFA. The 
Agricultural Education Magazine, 27(6). 124.

Border, J. (1936, March). Leadership training for future farmers. The Agricultural Education Magazine, 8(9), 134-138.

Bryant, B. (2001). History of the Virginia FFA association. Unpublished master's thesis, Virginia Polytechnic Institute and State University, Blacksburg.

Chickering, A. (1983). Education and identity. San Francisco: Jossey-Bass.

Credle, F. (1922). A suggested plan for cooperative organization work among farm boys and girls. Unpublished master's thesis, Virginia Polytechnic University.

Duerst, E. (1935). State leadership conferences. The Agricultural Education Magazine. 7(10). 158.

Fenn, G. (1964). Working with young people in self-determined projects. Burlington, VT: University of Vermont.

Forbush, W. (1909). Boys' clubs. An address before the conference on child welfare at Clark University, Worcester, July 1909.

Fraenkel, J. \& Wallen, N. (1999). How to design and evaluate research in education. New York: McGraw-Hill.

Frysinger, G. (1931). Local leadership in cooperative extension work. Paper read before the National Conference on Parent Education, called by the U.S. Commissioner of Education, at Hot Springs Arkansas, May $1,1931$.

Graham, A. (1902-1952). Papers (archival). Columbus, OH: Ohio State University.

Hammonds, B. (1950). Teaching agriculture. New York: McGraw-Hill.

Hillison, J. \& Williams, S. (2001). When FFA was king of the radio airwaves. Journal of Agricultural Education. 42(2). 11-17.

Hoover, H. (1950). Analysis of FFA leadership. Unpublished master's thesis, Texas Tech College, Lubbock, TX.

Jackson, L. (1934). Ohio FFA leadership conference. The Agricultural Education Magazine. 6(11). 172.

Knapp, S. (1904). The work of the community demonstration farm at Terrell, Texas. Washington, DC: U.S. Department of Agriculture.

Knauer, D. (1950). A recommended procedure for Future Farmers of America leadership training programs in Pennsylvania. Unpublished master's thesis, Pennsylvania State University, University Park.

Letterman, D. (2002). Indianapolis born comedian, talk show host. Retrieved on May 17, 2006, from http://www2.indystar.com/library/factfiles/ people/l/letterman_david/letterman.html.

Lewis, R. (c. 1970). 4-H teen agent. University Park, PA: Pennsylvania State University.

Montgomery, C. (1928). Rural leadership: With special reference to leadership problems in boys' and girls' 4-H club work. Unpublished master's thesis, Virginia Polytechnic Institute, Blacksburg, VA.

Moore, G. (1988). The forgotten leader in agricultural education: Rufus Stimson. $J$. AATEA. 29(3). 50-58.

National Education Association. (18581925). Journal of Proceedings and Addresses of the 4lst Annual Meeting (1902). Minneapolis, MN: The Association.

National 4-H. (2004). 4-H centennialhistory. Retrieved November 8, 2004, from http://www.4hcentennial.org/history/categor y.asp? catid $=25$. 
National FFA. (1938). Revised manual for future farmers of america. Baltimore, MD: French-Bray.

National FFA. (2000a). Advisor's guide to the FFA student handbook. Indianapolis, IN: Author.

National FFA. (2000b). FFA Student manual. Indianapolis, IN: Author.

National FFA. (2001). Official FFA manual. Indianapolis, IN: Author.

National FFA. (2005). History of FFA. Retrieved August 18, 2005, from http://www.ffa.org/about_ffa/html/ffa_histor y.htm.

National FFA. (2006, May). LifeKnowledge at-work newsletter. Retrieved June 23, 2006 from http:/www. ffa.org/ageducators/lifeknowledge/newslette r/lk_newsletter_0605.html

National FFA (n. d). Special collections 1916-2000. Retrieved May 6, 2002, from IUPUI University Library, Indianapolis, IN. www.ulib.iupui.edu/special/ffa/ mss035.html.

Newberry, C., Couch, M., Howard, J., \& Boleman, C. (2001). Evaluation of SPECTRA 2000, an annual program in Texas 4 -H. In Couch, M, Howard, J. \& Boleman, C. Texas 4-H Research Review (2000-01). Texas Agricultural Extension Service. College Station, TX.

Ross, W. (1939). Forward FFA leadership for future farmers, agriculturists and advisors. Baltimore, MD: French-Bray.

RKO Pictures, Inc. (1949). Green promise (released as Raging Waters in the United Kingdom and Verdes Horizontes in Mexico), 100 minutes.

Scholl, J. (2004). Making the best better: Sixteen hundred 4-H graduate studies. University Park, PA: Pennsylvania State University.
Scholl, J. (2005a). FFA graduate studies: Unpublished bibliography. University Park, PA: Pennsylvania State University.

Scholl, J. (2005b). 4-H and FFA fiction: Unpublished bibliography. University Park, PA: Pennsylvania State University.

Schutt, R. (2001). Investigating the social world. The process and practice of research (3rd ed.). Thousand Oaks, CA: Pine Forge Press.

Shambaugh, J. (1911). The corn lady: The story of a country teacher's work. New Haven, CT: Microform, Reel 855(6990).

Shinn, E. (1928). Objectives in a program of rural life. Washington, D.C.: U.S. Department of Agriculture.

Smith, R. B. (1933). Couchdale FFA camp and its functions. The Agricultural Education Magazine. 6(3), 46-47.

Stewart, R. \& Getman, A. (1927). Teaching agricultural vocations - A manual for teachers and preparation and in service. New York, NY: John Wiley \& Sons.

Tenney, A. (1977). The FFA at 50. Indianapolis, IN: National FFA.

Twentieth Century-Fox. (1934). Young America, 73 minutes.

Universal Pictures (1961). Tomboy and the champ, 92 minutes.

USDA (1913). Helping the farmer of tomorrow. College Park, MD: Archives II, 33(19), 3 min.

USDA (1920a). Club champions at Camp Vail. College Park, MD: Archives II, 33(44), 12 min.

USDA (1920b). Cured by canning. College Park, MD: Archives II, 33(28), 26 $\min$. 
USDA (1927). The 4-H camp for boys and girls. College Park, MD: Archives II, 33(19), $16 \mathrm{~min}$.

USDA (1973). Mulligan stew. Washington, DC: author, $180 \mathrm{~min}$.

Vallot, J. (1963). 33 years of leadership development through the FFA in Louisiana. Louisiana Association Future Farmers of America.

Van Linden, J., \& Fertman, C. (1998). Youth Leadership - A guide to understanding leadership development in adolescents. San Francisco: JosseyBass.

Van Rensselaer, M. (1900-1905). Letters (archival). Ithaca, NY: Cornell University. Index 23-2-749 (Box 49).
Vines, C., \& Anderson, A. (1976) Eds. Heritage horizons: Extension's commitment to people. Madison, WI: Journal of Extension.

Virginia FFA Association. (n. d.). The birth and development of the future farmers of Virginia. Retrieved April 19, 2002, from www.vaffa.org/history/hist_ffv.html

Wakefield, G.N. (1932). Training for leadership through the future farmers of America. Unpublished master's thesis, University of Florida, Gainesville..

Wall, C. (1960). A more effective FFA. Danville, IL: Interstate.

Wessel, T., \& Wessel, M. (1982). 4-H: An American idea 1900-1980: A history of 4-H. Chevy Chase, MD: National 4-H Council.

TRACY S. HOOVER is a Professor in the Department of Agricultural and Extension Education at The Pennsylvania State University, 323 Agricultural Administration Building, University Park, PA 16802. E-mail: tsh102@psu.edu.

JAN F. SCHOLL is an Associate Professor in the Department of Agricultural and Extension Education at The Pennsylvania State University, 323 Agricultural Administration Building, University Park, PA 16802. E-mail: jscholl@psu.edu.

ANNE H. DUNIGAN is a Program Analyst with the Animal Plant Health Inspection Service, USDA. E-mail: ahd116@yahoo.com

NADEZHDA MAMONTOVA is an International Program Support Coordinator, Technology Management Company, 14900 Conference Center Drive, Chantilly, VA 20151. 